\title{
Manifesti e bozzetti di scena: la danza come metafora del corpo
}

\author{
Starlight Vattano
}

\section{Abstract}

L'articolo si sofferma sullo studio delle alterazioni formali e sulle configurazioni del corpo umano nei bozzetti dei costumi di scena e nei manifesti pubblicitari della prima metà del Novecento. La letteratura offre un ampio panorama sulle produzioni grafiche realizzate per la divulgazione delle innovazioni teatrali nell'ambito delle tecniche e dei materiali pensati per sorprendere una società ormai ingerita dai suoni stridenti della velocità; rimane tuttavia aperta la questione relativa alla lettura compositivo-segnica dei valori cinetici e spaziali. Questo studio offrirebbe un approfondimento sulle connessioni tra il corpo nello spazio teatrale e la sua rappresentazione nell'esecuzione del movimento, per osservare il processo di trasfigurazione del corpo nel luogo del disegno.

La lettura delle immagini prese in esame guarda alle possibilità dispiegate dalle rappresentazioni del corpo che si muove dentro la 'maschera scenica' con l'obiettivo di riconoscere nelle strategie compositive adottate un vocabolario di segni atti a descrivere gli stati di moto del danzatore. La disposizione degli elementi, la struttura geometrica, gli effetti cromatici, la collocazione dei testi, le metafore grafiche sono alcuni dei valori sui quali il saggio si concentra, ricostruendo un periodo della storia dell'immagine fortemente legato alla trasformazione del corpo nello spazio, attraverso il progetto del costume di scena, nella qualità di simulacro del ballerino e di suo doppio.
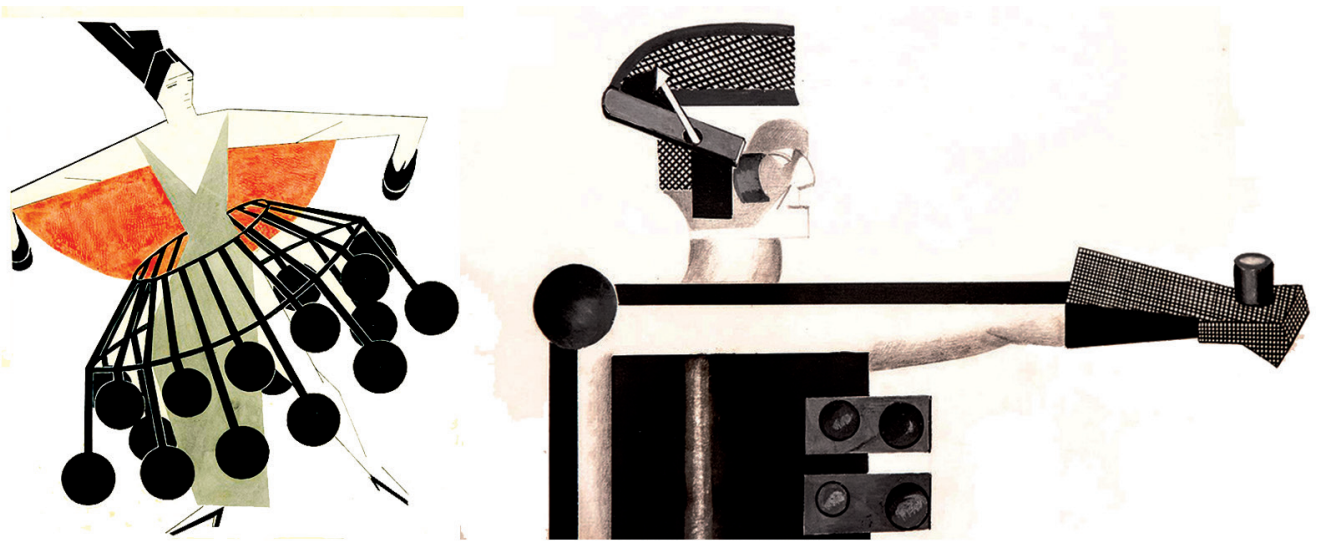
"Dalle tenebre si vede nascere con stupore una forma bluastra da uccello notturno [...] poco a poco si precisa e si impone la grande creatura di nuvola lunare [...] e a un tratto si colora, risplende con esplosione fulminea [...] quindi rivolgendosi brucia, interamente divenuta vortice, ellisse, fiore, calice eccezionale, farfalla, uccello colossale, traccia rapida e multipla di tutte le forme dalla fauna alla flora [... Ella figura il ritorno tramite il fuoco alle forme primordiali dell'infinito al di sopra delle passioni e del grido" [Carandini 1996, p 6]. Le parole del poeta simbolista Camille Mauclair, tessere di un linguaggio metaforico carico di significati allegorici, si trasformano in immagini fantastiche per rievocare uno dei famosi spettacoli che la ballerina americana Loïe Fuller tenne al Thèâtre-Musée Loïe Fuller esibendosi nelle sue danses lumineuses in un momento in cui alla grande celebrazione industriale Parigi rispondeva con l'Exposition Universelle del 1900.

Nel buio totale di un piccolo teatro si poteva assistere all'incandescenza di un corpo che si espandeva nello spazio attraverso grandi e leggerissimi tessuti bianchi di seta sostenuti da lunghe pertiche, mossi al ritmo della luce, pròtesi di quelle gradazioni luminose ottenute dalle recenti tecnologie del gas illuminante.

Il movimento rotatorio e sinuoso del bianco materico nascondeva completamente il corpo della danzatrice restituendo agli occhi degli spettatori un'eterea visione, una parvenza effimera dello spazio-luce nel linguaggio sonoro wagneriano, alla ricerca di un codice comunicativo in assenza di parole. Come reazione alla tradizione ballettistica del secolo precedente, Loïe Fuller incarnò la voce della trasformazione del corpo in movimento sotto la luce, una visione della forma foriera di quelle riflessioni che, di lì a breve, avrebbero sviluppato molti degli artisti dell'avanguardia italiana e della scena internazionale.

La definizione grafica del costume di scena indossato rivela il carattere del personaggio rappresentato, la linea che avvolge il corpo nei bozzetti o nei manifesti assume la funzione di moltiplicatore delle possibilità di spostamento: la struttura del movimento viene letta in relazione al potere simbolico evocato dagli effetti dinamici della composizione. Nel 1889

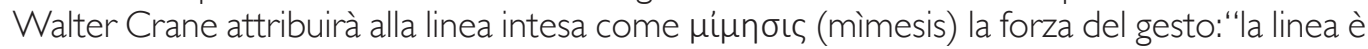
di importanza assoluta: nella realizzazione dell'opera d'arte il disegnatore [...] deve servirsi di linee di ogni tipo: linea determinante, linea enfatica, linea delicata, linea aggressiva, linea che controlla e unisce" [Vinca Masini 2000, p. 46].

Nei disegni di Henri de Toulouse-Lautrec e di Koloman Moser questa linea 'controlla e unisce' le movenze serpentine della danzatrice che si trasforma nel suo stesso movimento, modella a spirale lo spazio e d'improvviso viene inghiottita dal sipario (fig. I).

Ed è questa forma di abbandono del corpo al movimento nella luce, sotto l'estenuante peso della forza di gravità, che viene catturata nelle rappresentazioni della Fuller: il suo costume le nasconde il viso, confonde i lineamenti corporei, ma ne intercetta la mutazione nel tempo. Jules Chéret, per uno degli spettacoli alle Folie-Bergère, ne traccia delicatamente il corpo
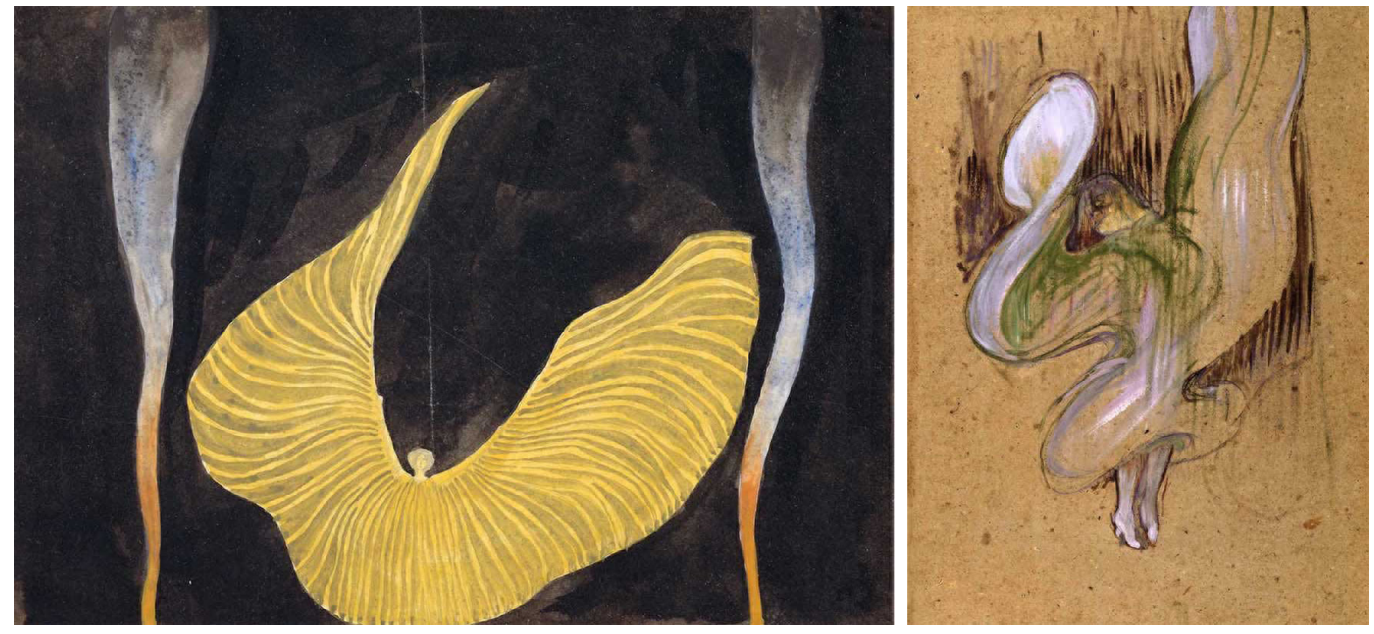
tratteggiato dietro i leggeri tessuti che servono ad accentuarne la sintassi gestuale e trasformano la figura della ballerina in movimento. I capelli illuminati dalla luce si fanno rossi e si dissolvono in un gesto circolare, nei teli di seta, non più bianchi, ma verdi e arancioni. Uno sfondo nero isola la figura nel suo movimento, la avvolge di spazio e la inserisce tra due righe di testo, anch'esse campite di rosso, in cui si incastra il piede della ballerina.

Lo stesso espediente grafico di forte contrasto cromatico fra i colori illuminati della danzatrice e lo sfondo dello spazio scenico completamente nero è adottato dal pittore Jean de Paléologu che regola le luci e i movimenti sul corpo di Loïe Fuller, descrivendo la propagazione, dal basso verso l'alto, di un gesto unico: il corpo viene arrestato in un salto, all'apertura delle braccia, mentre la testa si rivolge verso la platea.

Questi entusiasti studenti dell'École des Beaux Arts rievocano l'immagine descritta dai poeti simbolisti, di una donna che diventa vortice, fiamma e movimento nel pulviscolo di ombre e luci, di una figura che affascina letterati e artisti del tempo, in cerca di una smaterializzazione del corpo nello spazio delle impressioni (fig. 2).

Con i primi manifesti dedicati all'interpretazione del corpo che danza la tecnica grafica e pubblicitaria si affına nel cogliere le qualità del soggetto descritto e se nel caso di Loïe Fuller la luce incandescente e i leggerissimi tessuti bianchi costituiscono la parola chiave del testo, nelle rappresentazioni prodotte per la coppia di danzatori Clotilde e Alexandre Sakharoff saranno le grandi macchie colorate su carta a matita e tempera a descrivere la ricchezza dei tessuti e lo sfarzo delle scenografie.

Nella sua attività di costumista e bozzettista Alexandre Sakharoff sarà aspramente criticato per l'uso eccessivo del colore nei costumi e per l'estremo senso decorativo, valori che sembravano incarnare la forte dipendenza del disegno dalla sua principale attività: la danza. Il bozzetto di costume, nelle sue rappresentazioni, viene completamente inglobato dalla scenografia, il corpo si perde tra i fasti dei drappeggi e gli idilli delle favole teatrali, spesso intrisi di mitiche reminiscenze. Nella rappresentazione realizzata per Amore e Psyché, del 1927, l'atmosfera cromatica fa ancora da eco ai lavori scenografici prodotti per i Balletti Russi di tradizione bakstiana, grandi porzioni di carta colorata costruiscono una scena sinuosa in cui Sakharoff incastona il bozzetto di costume che si fluidifica insieme al sipario.
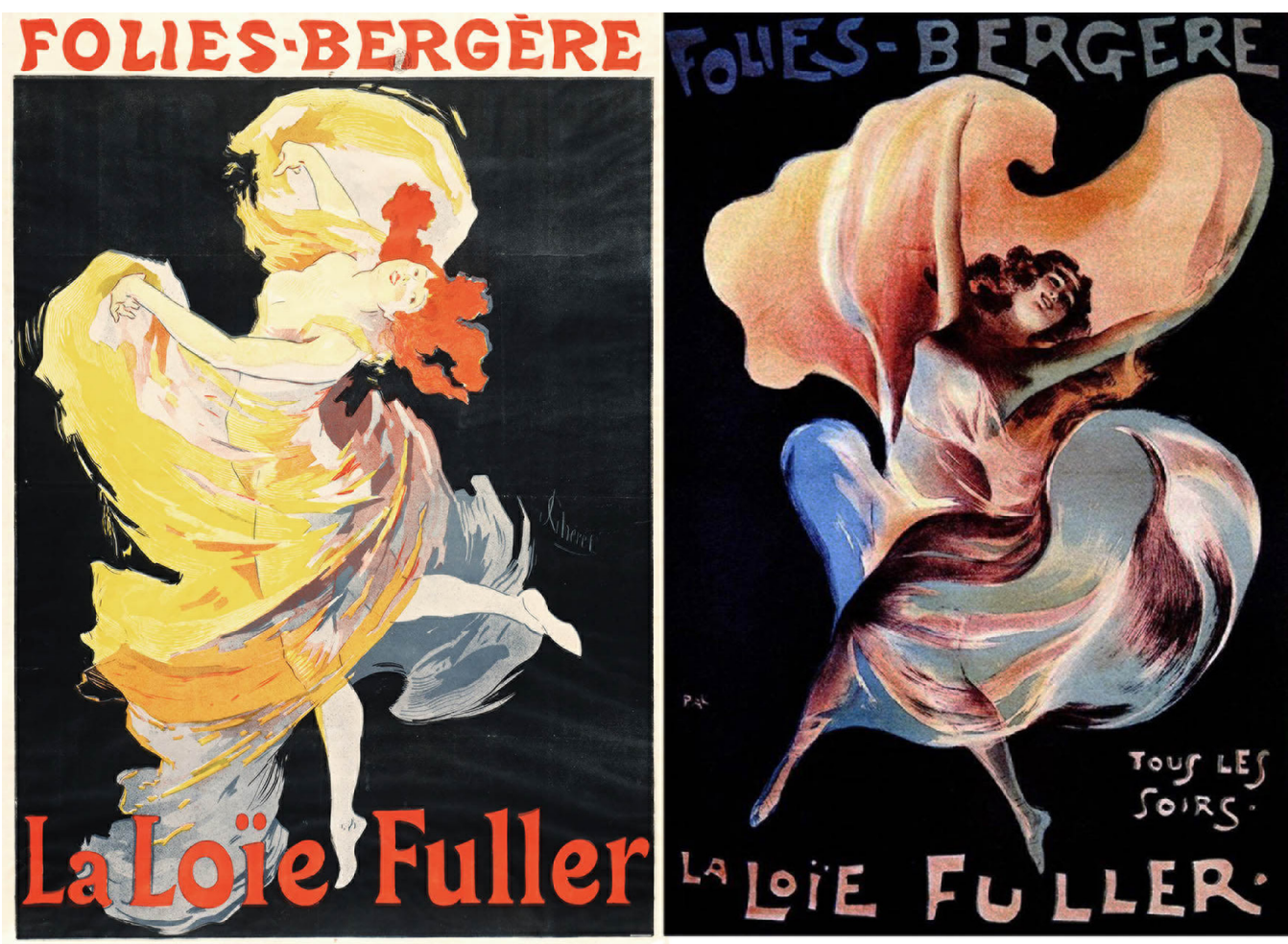
La città di sfondo appiattisce la rappresentazione, la ballerina sembra appoggiata alla superficie geometrizzata da pattern specchiati e, con un salto di scala, i due grandi vasi di fiori incorniciano lo spazio teatrale, uno spazio figurato che rimarrà assopito allo stato di ideazione (fig. 3).

Nel mistico paesaggio pensato per Un racconto russo di A. Kuprin (fig. 4), nel 1921, il bozzettista ripropone la tecnica del collage per ricostruire cromaticamente interni di chiese e icone russe, un'atmosfera nazionalista che iniziava ad essere lontana dai nuovi programmi di sala, come conferma una lettera che lo stesso Alexandre scriveva al figlio del pittore Andrea Jawlensky: "siccome è un pò troppo 'russo', potremmo trovarlo insoddisfacente per noi, perché tu sai che i nostri balli sono molto individuali e privi di qualsiasi colore nazionale" [Veroli 1991, p. 74].

A partire dalla seconda metà del XIX secolo in Russia ebbe inizio un processo di rinnovamento dell'arte, meglio noto come 'realismo archeologico', basato sull'uso di fonti etnografiche, che vide coinvolti storici, architetti e archeologi nel ripensamento della messinscena, ormai troppo lontana dal romanticismo esotico del bavarese Vladimir Stasov. In occasione dell'allestimento del dramma La morte di Ivan il terribile di Lev Tolstoj nel I867, il pittore Vjačeslav Švarc rivela tre aspetti diversi dello zar attraverso il disegno di tre bozzetti-ritratto; il valore estetico-creativo si aggiunse presto alla veridicità del dato storico, introdotto con i primi figurini vetero-russi disegnati da Ivan Gornostaev, fornendo al personaggio non soltanto l'abito, ma anche l'atteggiamento. L'interiorità del soggetto sarà metaforizzata attraverso la costruzione dell'immagine, incarnando il lirismo della musica nell'interpretazione del corpo sulla scena, una modalità di rappresentazione del personaggio che avrebbe anticipato le ricerche sul rapporto luce-colore di artisti come Kandinskij, Bakst e molti altri.

Il lavoro di Aleksandr Simov costituì l'elemento di passaggio dalla tradizione vetero-russa ai disegni di matrice costruttivista per il teatro. II giovane illustratore sperimenterà uno dei

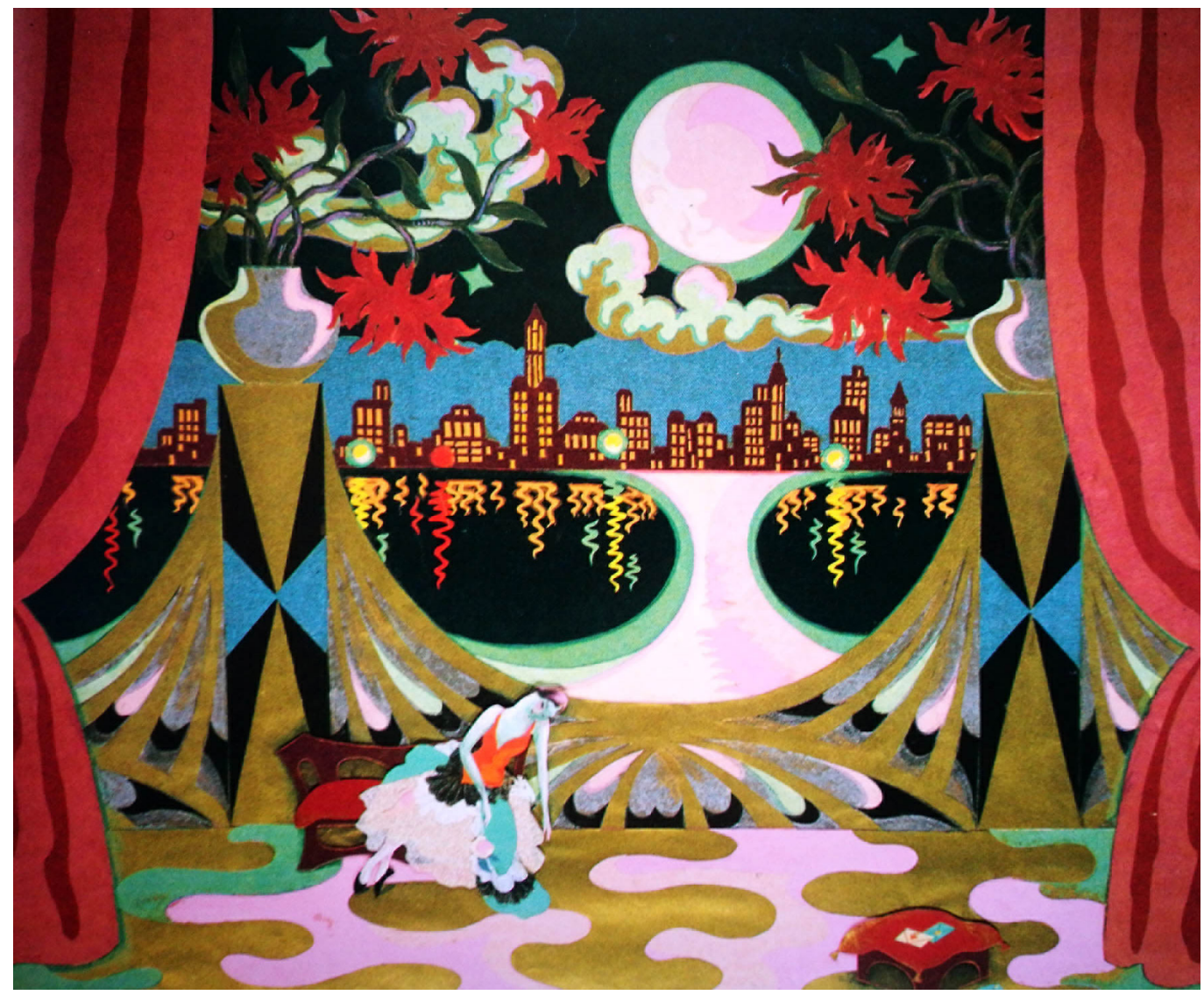


primi allestimenti di tragedia greca nel teatro russo, mettendo in scena nel 1899 al Teatro d'Arte di Mosca l'Antigone di Sofocle.

La sua visione spaziale, cadenzata dalla proporzione classica e dalla geometria dei corpi, si concretizzerà nel sistema linguistico adottato dalla generazione artistica successiva sulla geometrizzazione del costume mantenendo l'omogeneità della figura umana. Questa modalità di osservazione e trascrizione del costume di scena sarà sviluppata da Alexandra Exter e da Aleksander Vesnin che operavano sull'intersezione di piani cromatici sovrapponendoli tra loro e ottenendo una rigorosa ricostruzione del corpo nello spazio.

Soltanto poco tempo dopo, nel 1913, Kasimir Malevič avrebbe messo in scena Vittoria sul sole operando sui corpi dei ballerini attraverso una sintesi geometrica per porzioni; la sagoma umana veniva ritagliata secondo geometrie semplici e colorata con uniformi pennellate di acquerello che accentuavano la percezione emotiva della costruzione scenografica richiamando alla vaporosità trasparente dei tessuti.

Aleksandr Rodčenko giunse alla sostituzione della figura umana con il linguaggio di quadrilateri, cerchi e triangoli che riprendevano le direzioni delle diverse movenze sul palcoscenico e i rapporti dinamici con le scenografie.

La riflessione sulla trasfigurazione del corpo attraverso il costume di scena acquisisce una valenza socio-politica con la suite per orchestra Bolt (II bullone) composta da Dmitri Shostakovich, fra il 1930 e il 1931, che con il sarcasmo degli intellettuali comunisti dell'avanguardia artistica tenta di smascherare le ipocrisie della borghesia per mezzo di un balletto in tre atti in cui il protagonista, l'operaio di una fabbrica appena licenziato, incarna i valori di un lavoratore indolente, dichiarato avversario del sistema di governo sovietico.

Tatiana Bruni realizzò il progetto grafico dei costumi, caratterizzati da una scomposizione geometrico-cromatica attraverso la sovrapposizione di trame e materiali. Il costume viene indossato da corpi senza volto, la dinamica corporea pone l'accento sugli arti, le grosse campiture spezzate tracciano con forza le motilità e i pesi del movimento.

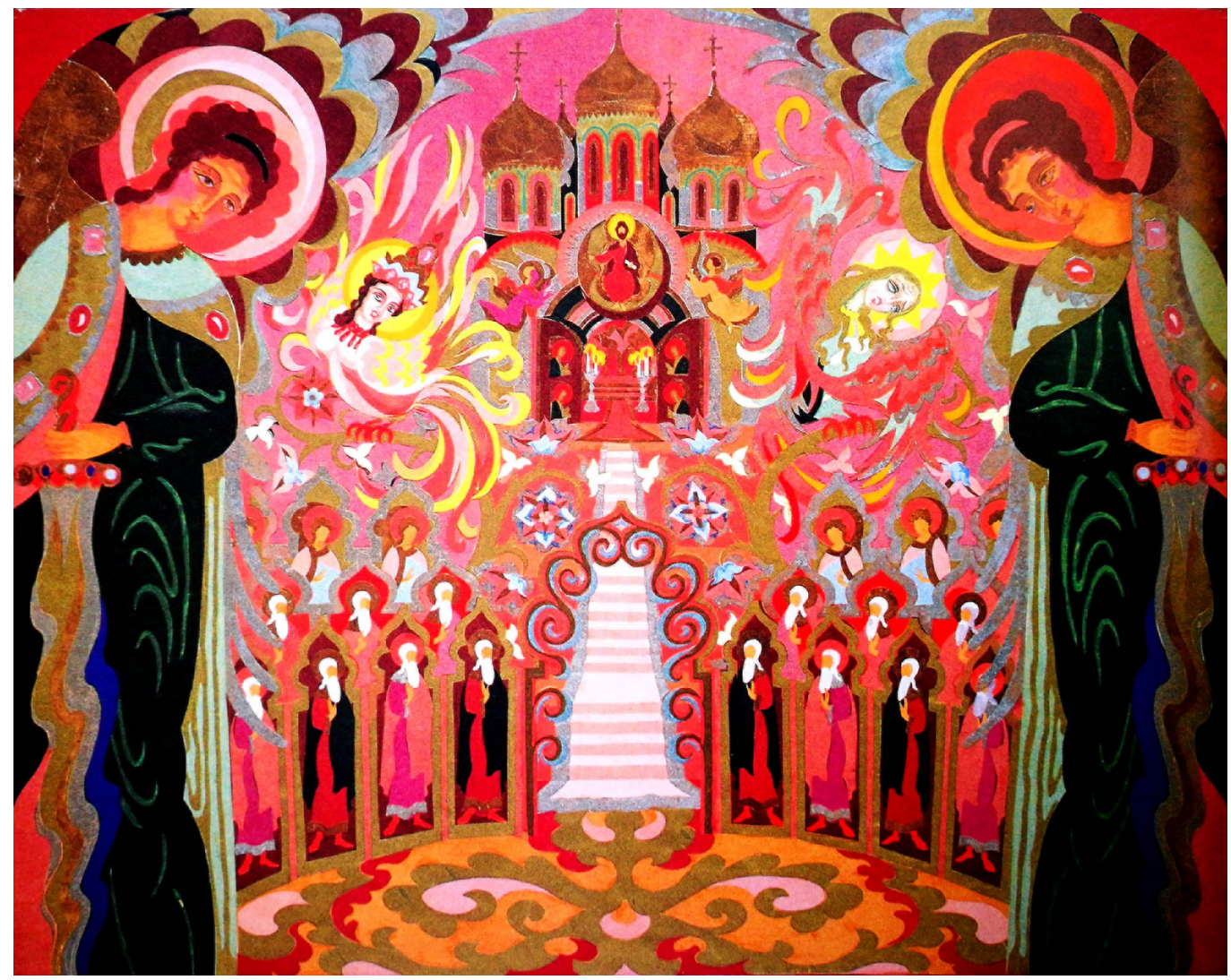


La funzione estetica dei bozzetti ricalca le qualità dinamico-corporee dei danzatori e i personaggi disegnati rispondono alla disposizione di forme semplici che assumono carattere in relazione alle testure dei materiali e alle stridenti disposizioni formali. In queste trasfigurazioni del corpo nel costume-segno, prevale quindi il rigore di una linea assente, ricostruita per somma di porzioni orientate e ordinate attraverso la differenziazione degli accostamenti materici (fig. 5).

Partendo dall'insegnamento di Malevič i progetti tipografici condotti da El Lissitzky nel 1923 sulla ricerca del 'nuovo enigma' per lo spettacolo elettromeccanico Vittoria sul sole danno forma alle Figurinen pensate come costruzioni geometriche in cui il corpo diviene leggibile soltanto a partire da una visione d'insieme delle forme.

La 'figura' umana viene completamente nascosta dall'ossatura geometrica, interrotta dai movimenti sincopati della macchina-uomo che esplora la multi-dimensione dello spazio-superficie aprendosi al tempo della costruzione nel vivere quotidiano (fig. 6).
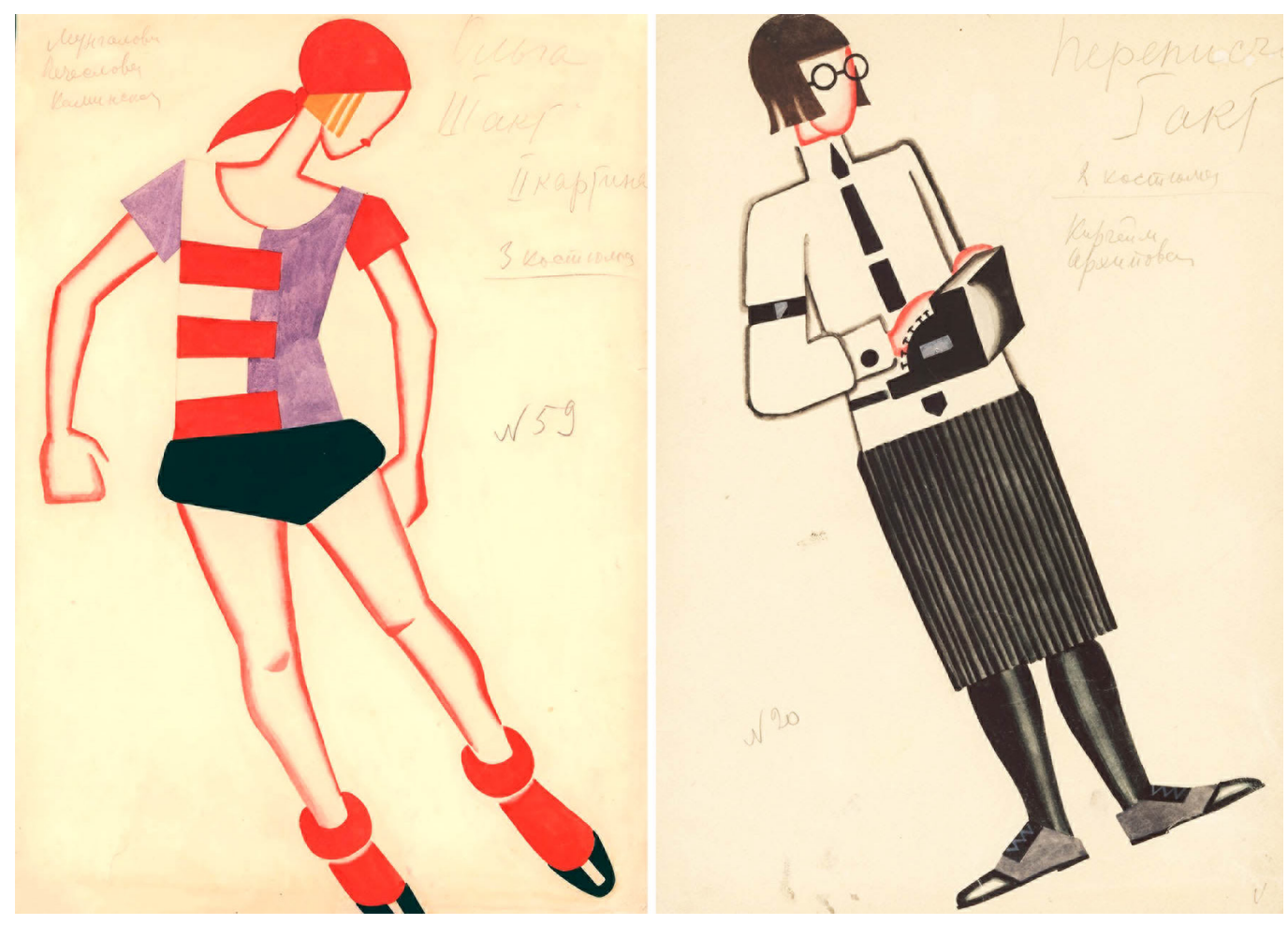

Un'importante connessione tra la dimensione della danza e quella della graficizzazione del corpo in movimento nello spazio è rappresentata dal sodalizio tra la coreografa Bronislava Nijinska e numerosi artisti tra cui Igor Stravinskij, Michail Larionov, Natalia Gončarova, Georges Braque e Pablo Picasso. Tra questi, una vasta produzione grafica sui costumi di scena è attribuita ad Alexandra Exter che, nel 1925, produsse un consistente numero di bozzetti per uno spettacolo privo di scenografie realizzato dalla stessa Nijinska la quale, proprio in quegli anni, stava definendo le sue teorie sulla coreografia e sulle composizioni astratte.

Sulla necessità di un movimento visualizzabile per la sua trascrizione grafica, la coreografa affermava: "non bisogna cominciare un balletto a partire dalla forma e poi costringere il movimento dentro questa forma predeterminata (impropria, senza vita) [...] II coreografo deve rendere il movimento visibile all'artista/interprete e deve insegnargli a rivelarlo e a renderlo a sua volta visibile allo spettatore" [Carandini 1996, p. 33]. 
L'attenzione viene quindi posta sulle microstrutture del ballerino nello svolgimento dell'azione che potenzia le sue doti dinamiche nello spazio, marcando soprattutto l'espressività del tronco e degli arti superiori. In questa visione del corpo trasformato nel disegno del movimento l'opera di Alexandra Exter si colloca come parte integrante del lavoro di costruzione coreografica, l'artista partecipava spesso alle lezioni di Nijinska, accogliendo regolarmente gli allievi danzatori nel suo atelier. Contaminazioni delle composizioni grafiche della Exter si trovano nei diari in cui la coreografa annotava le sue danze; si tratta di diagrammi caratterizzati da circonferenze, linee spezzate, archi, parabole e ovali, così come nei bozzetti di costumi realizzati dalla Exter.

II suo 'costruttivismo teatrale' viene trasposto dalla macchina-scenografica alla macchina-corpo quando la sua attenzione per l'ingranaggio degli arti si manifesta con forza nello spettacolo Thamyris Kithardos (Tamiri il Citaredo), che segnò l'avvio della collaborazione con Tairov nel 1915 al Teatro da Camera.
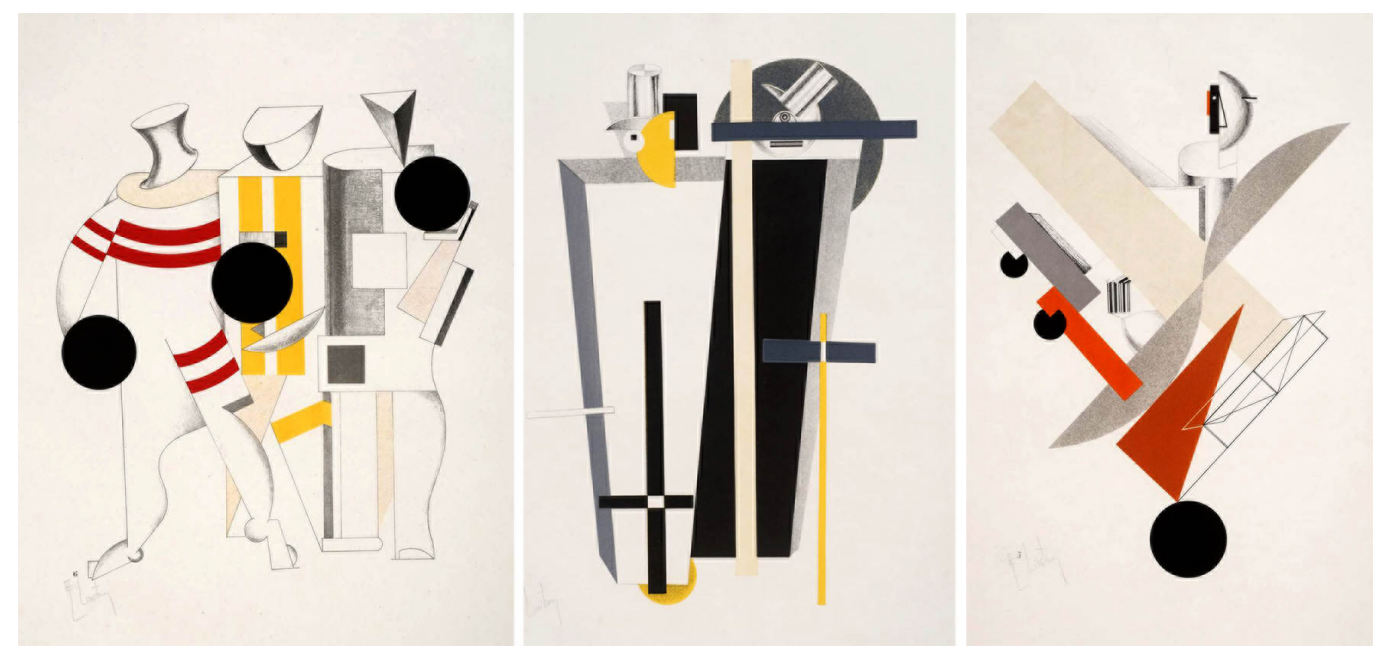

\section{Conclusioni}

La riflessione grafica sul costume-corpo costituisce un punto di incontro tra il mezzo segnico dello spazio teatrale in cui si muove il danzatore e lo spazio del disegno in cui si dispongono la forma e il colore. I costumi ricalcano la muscolatura dei danzatori e la struttura grafica riproduce una composizione ritmico-coreografica ponendo l'accento sulle qualità dinamiche dei corpi.

Emanazioni di segni e cromie, le rappresentazioni dei corpi trasfigurati nell'esecuzione del gesto, dalla mano di danzatori-costumisti, pubblicitari francesi o adepti dell'avanguardia artistica, costituiscono molteplici punti di contatto tra la poetica del corpo nella musica e la sua trasfigurazione nel vestito di scena.

La rappresentazione di questo 'doppio' celebra una mimica linguistica che introduce una sorta di métachorie [I], cioè un superamento della danza attraverso la parola del disegno.

\section{Note}

[I] Sul concetto di métachorie si veda il testo: Bentivoglio M., Zoccoli F. (2008). Le futuriste italiane nelle artivisive. Roma: De Luca Editori d'Arte, pp. I |-22. 
Fig. 7. Exter A., bozzetti per costumi di scen Costume per The Phantom Lady, 1924 (a sinistra); costumi per Aelita in Inhabitant of

Mars, 1924, (al centro
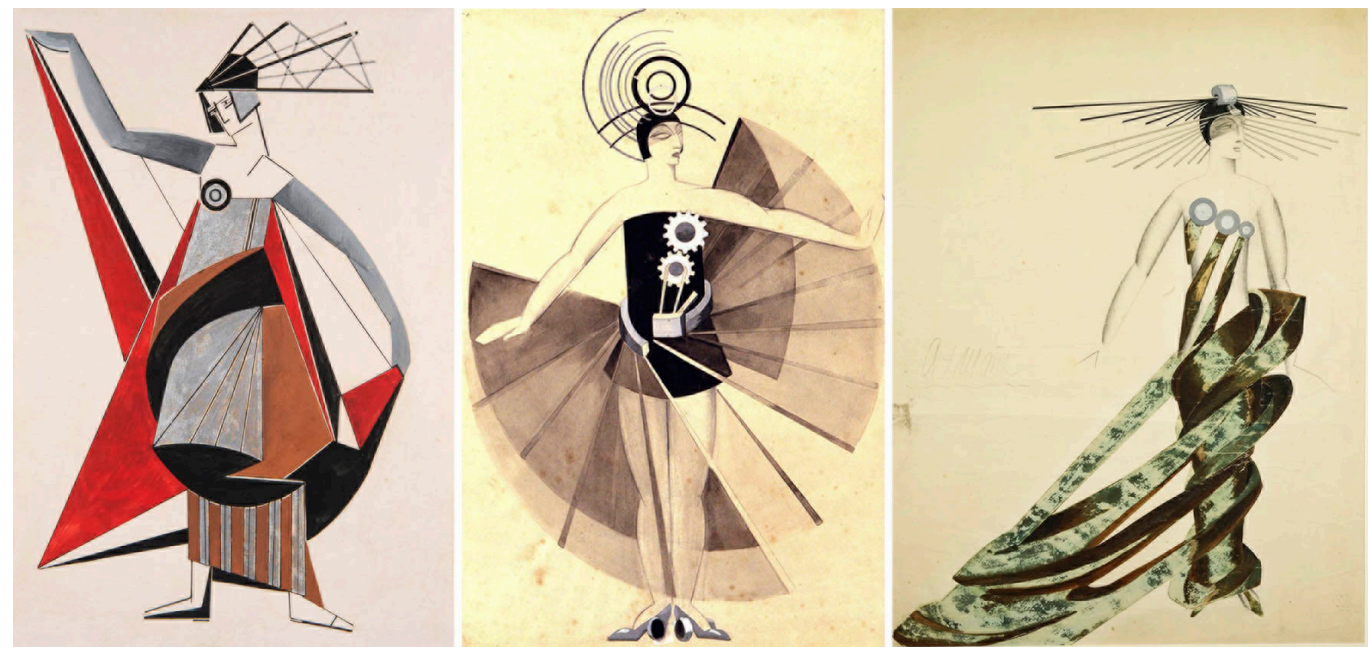

\section{Riferimenti bibliografici}

Bentivoglio Mirella, Zoccoli Franca (2008). Le futuriste italiane nelle artivisive. Roma: De Luca Editori d'Arte, pp. 254.

Bredekamp Horst (20।5). Immagini che ci guardano. Varese: Raffaello Cortina Editore.

Carandini Silvia (a cura di) (1996). L'astrazione danzata. Le arti del primo Novecento e lo spettacolo di danza. In Ricerche di Storia dell'Arte, n. 58. Roma: La Nuova Italia Scientifica.

Crane Walter (19|4). Line and form. Londra: London G. Bell

Pierantoni Ruggero (1999). Forma fluens. Il movimento e la sua rappresentazione nella scienza, nell'arte e nella tecnica. Torino: Bollati Boringhieri

Veroli Patrizia (a cura di). (199I). Un mito della danza fra teatro e avanguardie artistiche. Bologna: Edizioni Bora.

Vinca-Masini Lara (a cura di). (2000). Il Liberty. Art Nouveau. Firenze: Giunti

Autore

Starlight Vattano, Libera Università di Bolzano, starlight.vattano@unibz.it

Per citare questo capitolo:Vattano Starlight (2020). Manifesti e bozzetti di scena: la danza come metafora del corpo/Posters and stage sketches: dance as a metaphor for the body. In Arena A., Arena M., Brandolino R.G., Colistra D., Ginex G., Mediati D., Nucifora S., Raffa P. (a cura di). Connettere. Un disegno per annodare e tessere. Atti del $42^{\circ}$ Convegno Internazionale dei Docenti delle Discipline della Rappresentazione/Connecting. Drawing for weaving relationships. Proceedings of the 42th International Conference of Representation Disciplines Teachers. Milano: FrancoAngeli, PP. $1450-1465$. 


\title{
Posters and Stage Sketches: Dance as a Metaphor for the Body
}

\author{
Starlight Vattano
}

Abstract

The article focuses on the study of formal alterations and configurations of the human body in sketches of stage costumes and advertising posters of the first half of the twentieth century. The literature offers a broad overview of the graphic productions made for the dissemination of theatrical innovations in the field of techniques and materials designed to surprise a society now ingested by the strident sounds of speed; however, the question of the sign-compositive reading of kinetic and spatial values remains open. This study offers an in-depth examination of the connections between the body in the theatrical space and its representation in the execution of movement, to observe the process of transfiguration of the body in the place of drawing.

The reading of the images examined looks at the possibilities unfolded by the representations of the body moving within the 'stage mask' with the aim of recognizing in the compositional strategies adopted a vocabulary of signs capable of describing the dancer's states of motion. The arrangement of the elements, the geometric structure, the chromatic effects, the placement of the texts, the graphic metaphors are some of the values on which the essay focuses, reconstructing a period in the history of the image strongly linked to the transformation of the body in space, through the design of the stage costume, in the quality of simulacrum of the dancer and his double.

Keywords

dance, theatre costume sketch, advertising poster, movement, drawing.
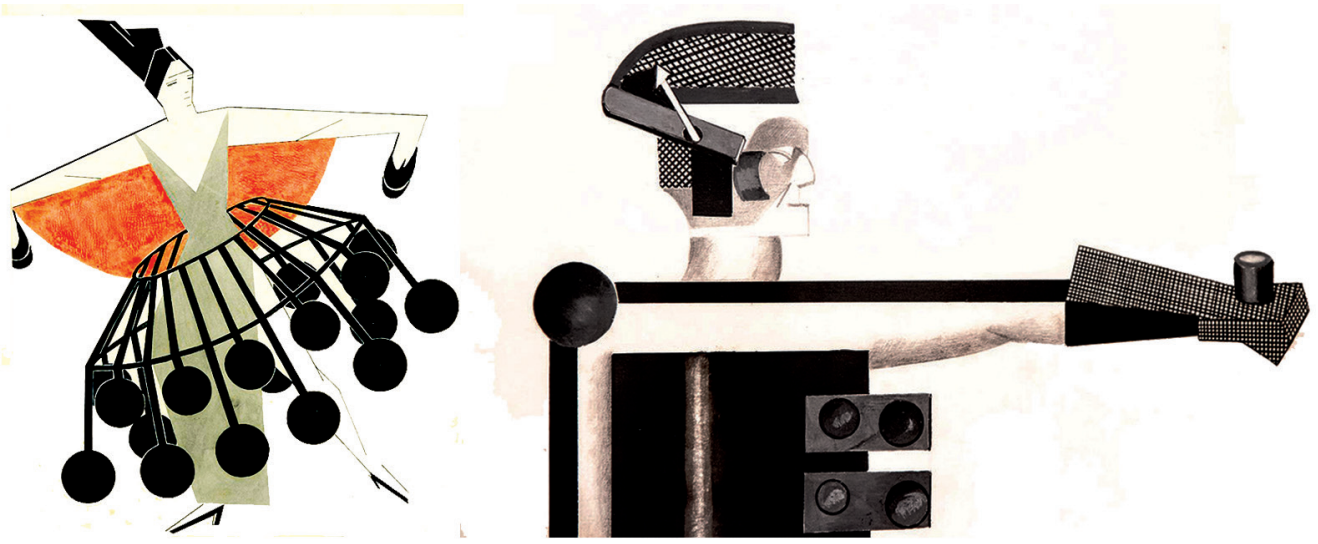
"From the darkness a bluish nocturnal bird form is seen to be born with amazement [...] little by little the great creature of the lunar cloud imposes itself [...] and all of a sudden it is coloured, it shines with a lightning explosion [...] and then turns to burn, entirely become vortex, ellipse, flower, exceptional chalice, butterfly, colossal bird, rapid and multiple traces of all forms from fauna to flora [...] She is the return through fire to the primordial forms of infinity above passions and screams" [Carandini 1996, p. 6]. The words of the Symbolist poet Camille Mauclair, pieces of a metaphorical language full of allegorical meanings, are transformed into fantastic images to evoke one of the famous shows that the American dancer Loïe Fuller held at the Thèâtre-Musée Loïe Fuller performing in her danses lumineuses at a time when the great industrial celebration Paris was responding with the Exposition Universelle of 1900.

In the total darkness of a small theatre one could witness the incandescence of a body expanding in space through large and very light white silk fabrics supported by long poles, moved to the rhythm of the light, pròthesis of those luminous gradations obtained by the recent technologies of the illuminating gas.

The rotating and sinuous movement of the white material completely hid the dancer's body, giving back to the spectators' eyes an ethereal vision, an ephemeral semblance of space-light in Wagnerian sound language, in search of a communicative code in the absence of words. As a reaction to the ballet tradition of the previous century, Loïe Fuller embodied the voice of the transformation of the body into movement under the light, a vision of the harbinger form of those reflections that would soon develop many of the artists of the Italian avant-garde and the international scene.

The graphic definition of the stage costume worn reveals the nature of the character represented, the line that wraps the body in the sketches or posters assumes the function of multiplier of the movement possibilities: the movement structure is read in relation to the symbolic power evoked by the dynamic effects of the composition. In I889 Walter Crane attributed to the line understood as $\mu$ innoıs (mimesis) the force of the gesture: "the line is of absolute importance: in the creation of the work of art the artist [...] must use lines of every kind: decisive line, emphatic line, delicate line, aggressive line, line that controls and unites" [Vinca Masini 2000, p. 46]. In the drawings by Henri de Toulouse-Lautrec and Koloman Moser this line "controls and unites" the serpentine movements of the dancer who transforms herself into her own movement, spirals the space and is suddenly swallowed up by the curtain (fig. I).

And it is this form of abandonment of the body to movement in the light, under the exhausting weight of the force of gravity,that is captured in Fuller's representations: her costume hides her face, confuses her body features, but intercepts her mutation over time. Jules Chéret, for one of the shows at the Folie-Bergère, delicately traces her body behind the light
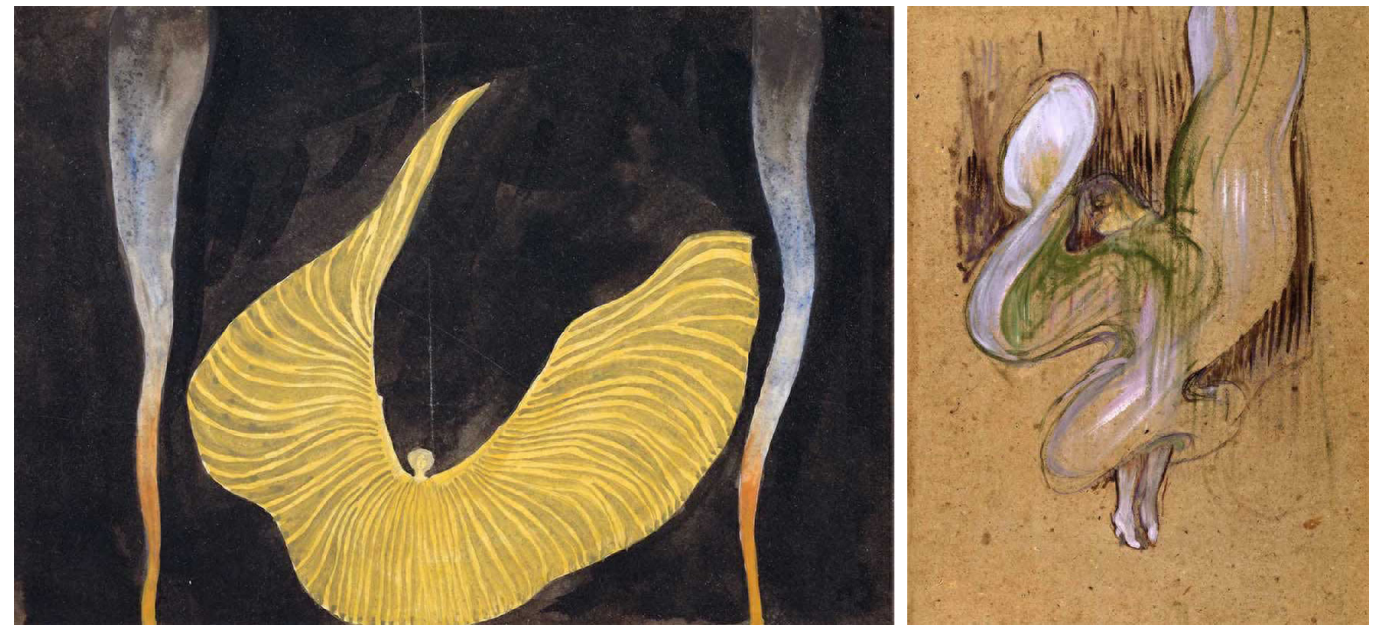
fabrics that serve to accentuate the gestural syntax and transform the figure of the dancer into movement. The hair illuminated by the light becomes red and dissolves, in a circular gesture, in the silk cloths, no longer white but green and orange. A black background isolates the figure in its movement, envelops it in space and inserts it between two lines of text, also filled with red, in which the dancer's foot is inserted.

The same graphic expedient of strong chromatic contrast between the dancer's illuminated colours and the background of the completely black stage space is adopted by the painter Jean de Paléologu who regulates the lights and movements on Loïe Fuller's body, describing the propagation, from bottom to top, of a unique gesture: the body is stopped in a leap, at the opening of the arms, while the head turns towards the audience. These enthusiastic students of the École des Beaux Arts evoke the image described by the Symbolist poets, of a woman who becomes vortex, flame and movement in the dust of shadows and lights, of a figure that fascinates scholars and artists of the time, in search of a dematerialization of the body in the space of impressions (fig. 2).

With the first posters dedicated to the interpretation of the dancing body, the graphic and advertising technique is refined in grasping the qualities of the subject described. Representing Loïe Fuller the incandescent light and the very light white fabrics constitute the key word of the text, while in the drawings produced for the couple of dancers Clotilde and Alexandre Sakharoff the large coloured stains on pencil and tempera paper describe the richness of the fabrics and the magnificence of the sets.

In his activity as costume designer and sketch artist Alexandre Sakharoff was harshly criticized for the excessive use of colour in costumes and for the extreme decorative sense, values that seemed to embody the strong dependence of drawing on his main activity: dance. The costume sketch, in his performances, is completely absorbed by the set design, the body is lost among the pomp of the drapes and the idylls of the theatrical fairy tales, often steeped in mythical reminiscences. In the 1927 performance for Cupid and Psyché, the chromatic atmosphere still echoes the scenographic works produced for the Russian Ballets in the Bakstian tradition, large portions of coloured paper create a sinuous scene in which Sakharoff sets the costume sketch that fluidifies with the curtain. The city in the background
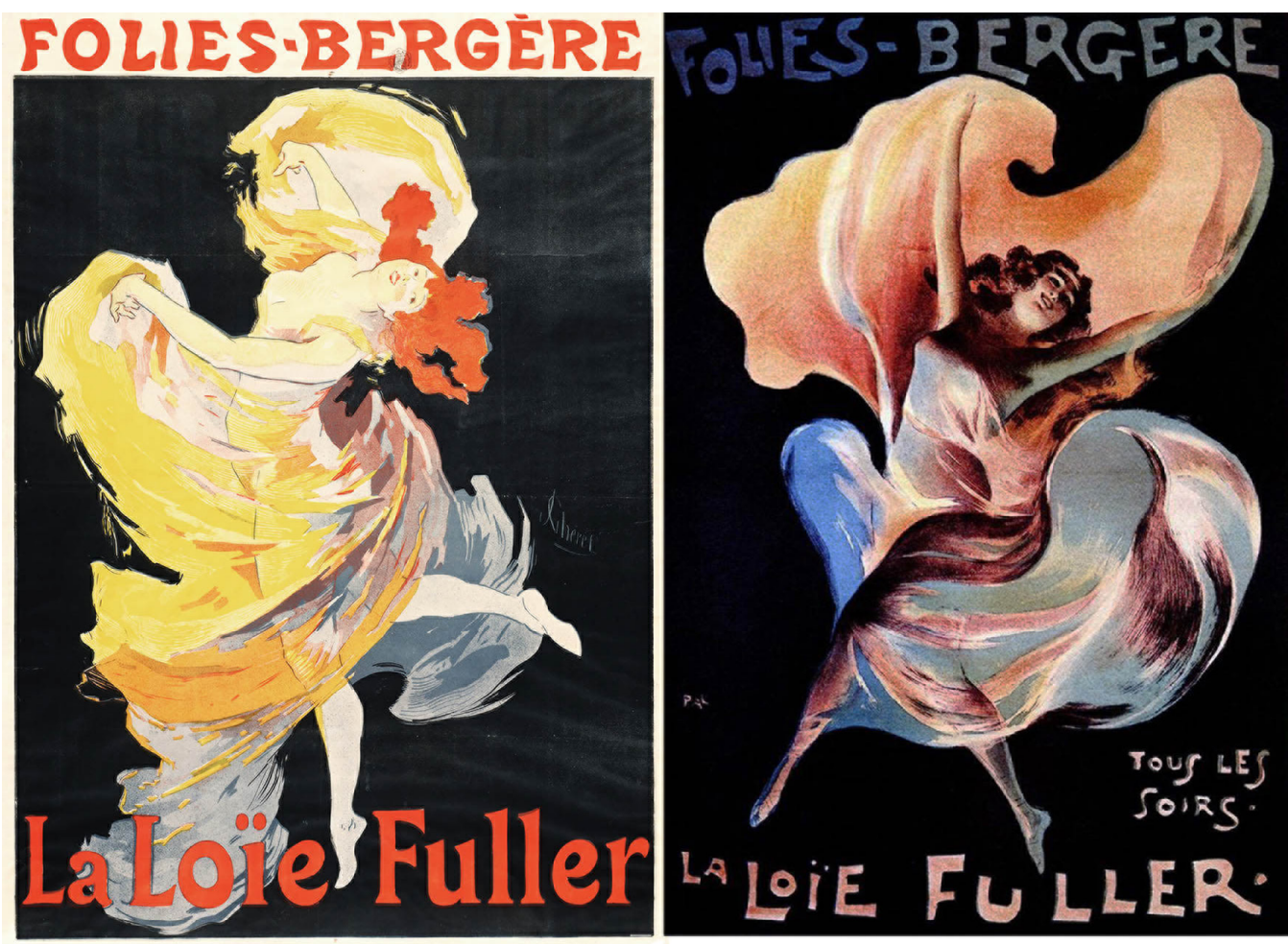
flattens the performance, the dancer seems to be leaning against the geometrical surface with mirrored patterns and, with a difference in scale, the two large flower vases frame the theatrical space, a figurative space that will remain asleep in the state of conception (fig. 3). In the mystical landscape designed for A. Kuprin's Russian tale (fig. 4), in 1921, the sketch artist reproposed the collage technique to reconstruct chromatically the interiors of Russian churches and icons, a nationalist atmosphere that was beginning to be far removed from the new hall programs, as confirmed by a letter that Alexandre himself wrote to the son of the painter Andrea Jawlensky: "since it is a little too 'Russian', we might find it unsatisfactory for us, because you know that our dances are very individual and devoid of any national color" [Veroli 1991, p. 74].

From the second half of the 19th century in Russia began a process of renewal of art, better known as archaeological realism, based on the use of ethnographic sources, which involved historians, architects and archaeologists in rethinking the staging, now too far from the exotic romanticism of the Bavarian Vladimir Stasov. On the occasion of the staging of the drama The Death of Ivan the Terrible by Lev Tolstoy in 1867, the painter Vjačeslav Švarc revealed three different aspects of the Tsar through the drawing of three sketch-portraits; the aesthetic-creative value was soon added to the truthfulness of the historical datum, introduced with the first veteran-Russian figurines designed by Ivan Gornostaev, giving the character not only the dress but also the attitude. The interiority of the subject will be metaphorized through the construction of the image embodying the lyricism of music in the interpretation of the body on stage, a mode of representation of the character that would have anticipated the research on the light-color relationship of artists such as Kandinsky, Bakst and many others.

Aleksandr Simov's work was the element of transition from the old-Russian tradition to constructivist drawings for the theatre. The young illustrator experimented with one of the

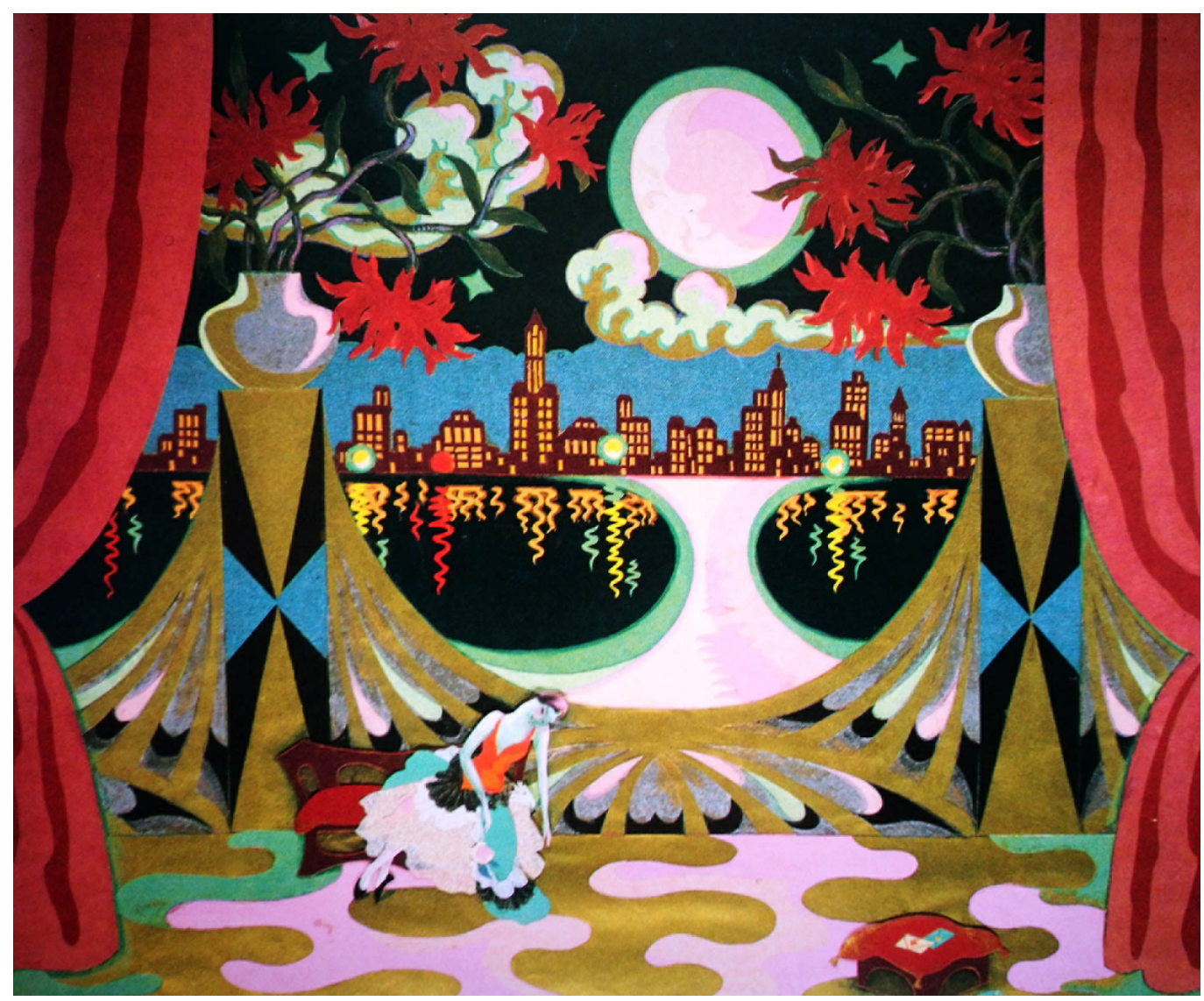


first stagings of Greek tragedy in Russian theatre, staging Sophocles' Antigone in 1899 at the Moscow Art Theatre.

His spatial vision, cadenced by the classical proportion and geometry of bodies, took shape in the linguistic system adopted by the following artistic generation on the geometrization of costume while maintaining the homogeneity of the human figure. This way of observing and transcribing the costume will be developed by Alexandra Exter and AleksanderVesnin who worked on the intersection of chromatic planes by superimposing them on each other, obtaining a rigorous reconstruction of the body in space.

Only a short time later, in 1913, Kasimir Malevič staged Victory over the Sun by working on the bodies of the dancers through a geometrical synthesis in portions; the human silhouette was cut out according to simple geometries and coloured with uniform watercolour brushstrokes that accentuated the emotional perception of the scenographic construction, recalling the transparent vapouriness of the fabrics. Aleksandr Rodčenko came to the replacement of the human figure with the language of quadrilaterals, circles and triangles that took up the directions of the different movements on stage and the dynamic relationships with the scenography.

The reflection on the transfiguration of the body through stage costume acquires a socio-political value with the orchestra suite Bolt (The Bolt) composed by Dmitri Shostakovich, between 1930 and 1931, who, with the sarcasm of the communist intellectuals of the artistic avant-garde, attempts to unmask the hypocrisies of the bourgeoisie by means of a ballet in three acts in which the protagonist, the worker in a factory that had just been fired, embodies the values of an indolent worker opposed to the system of Soviet government. Tatiana Bruni created the graphic design of the costumes, characterized by a geometric-chromatic decomposition through the overlapping of textures and materials. The costume is worn by faceless bodies, the body dynamics emphasizes the limbs, the large broken backgrounds strongly trace the motility and weights of the movement.

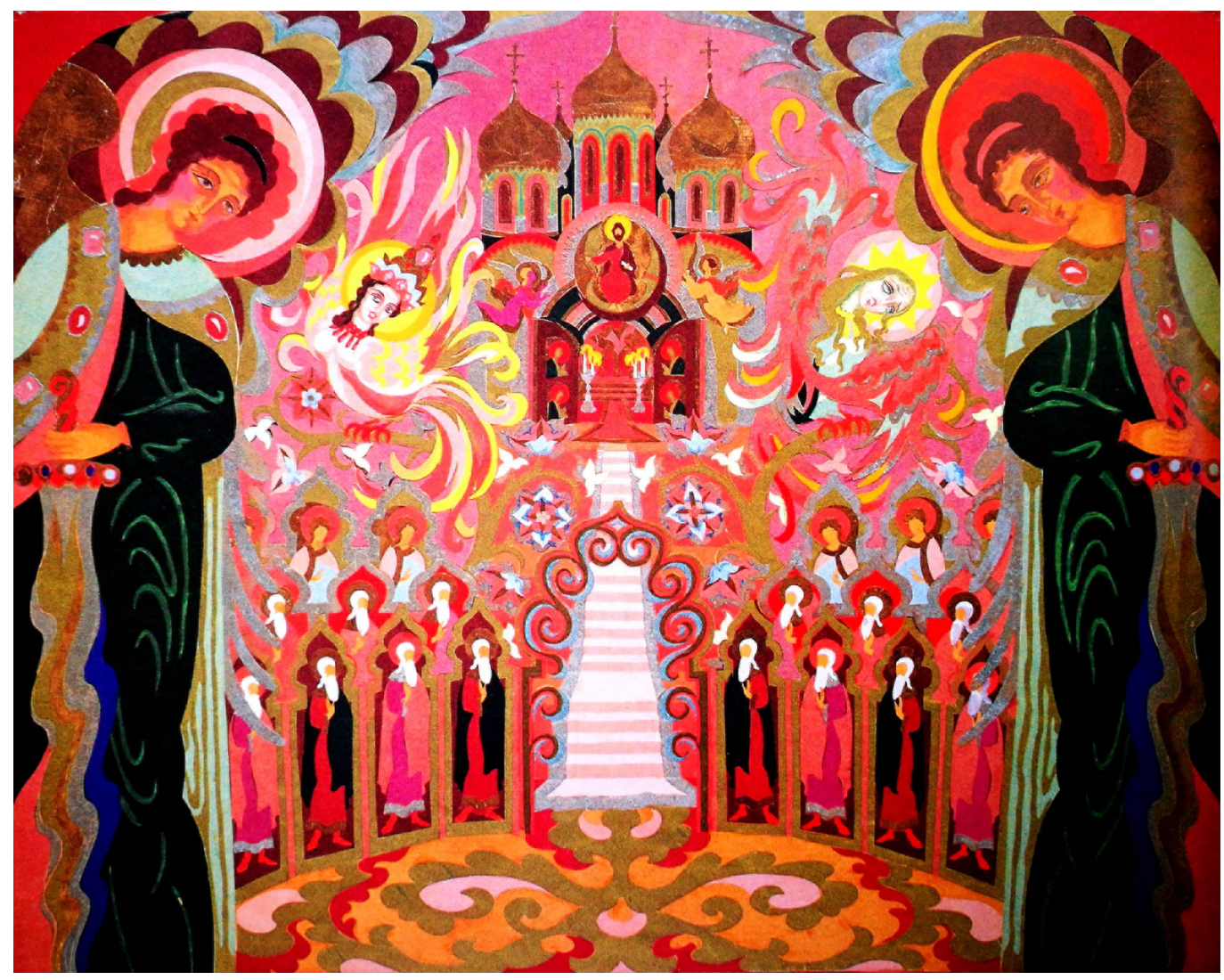


The aesthetic function of the sketches follows the dynamic-body qualities of the dancers and the characters designed respond to the arrangement of simple shapes that take on character in relation to the textures of the materials and the strident formal arrangements. In these transfigurations of the body in the costume-sign, the rigor of the absent line prevails, reconstructed by the sum of oriented and ordered portions through the differentiation of the material combinations (fig. 5).

Starting from Malevič's teaching, the typographic projects conducted by El Lissitzky in 1923 on the research of the 'new enigma' for the electromechanical show Victory over the Sun give shape to the Figurinen conceived as geometric constructions in which the body becomes readable only from an overall view of the forms.

The human 'figure' is completely hidden by the geometric framework, interrupted by the syncopated movements of the man-machine that explores the multi-dimension of the space-surface opening up to the time of construction in everyday life (fig. 6).

Fig. 5. Bruni T., sketches of costumes for the show The Bolt: Olga (on the left), The Typist, 1931 (on the right).

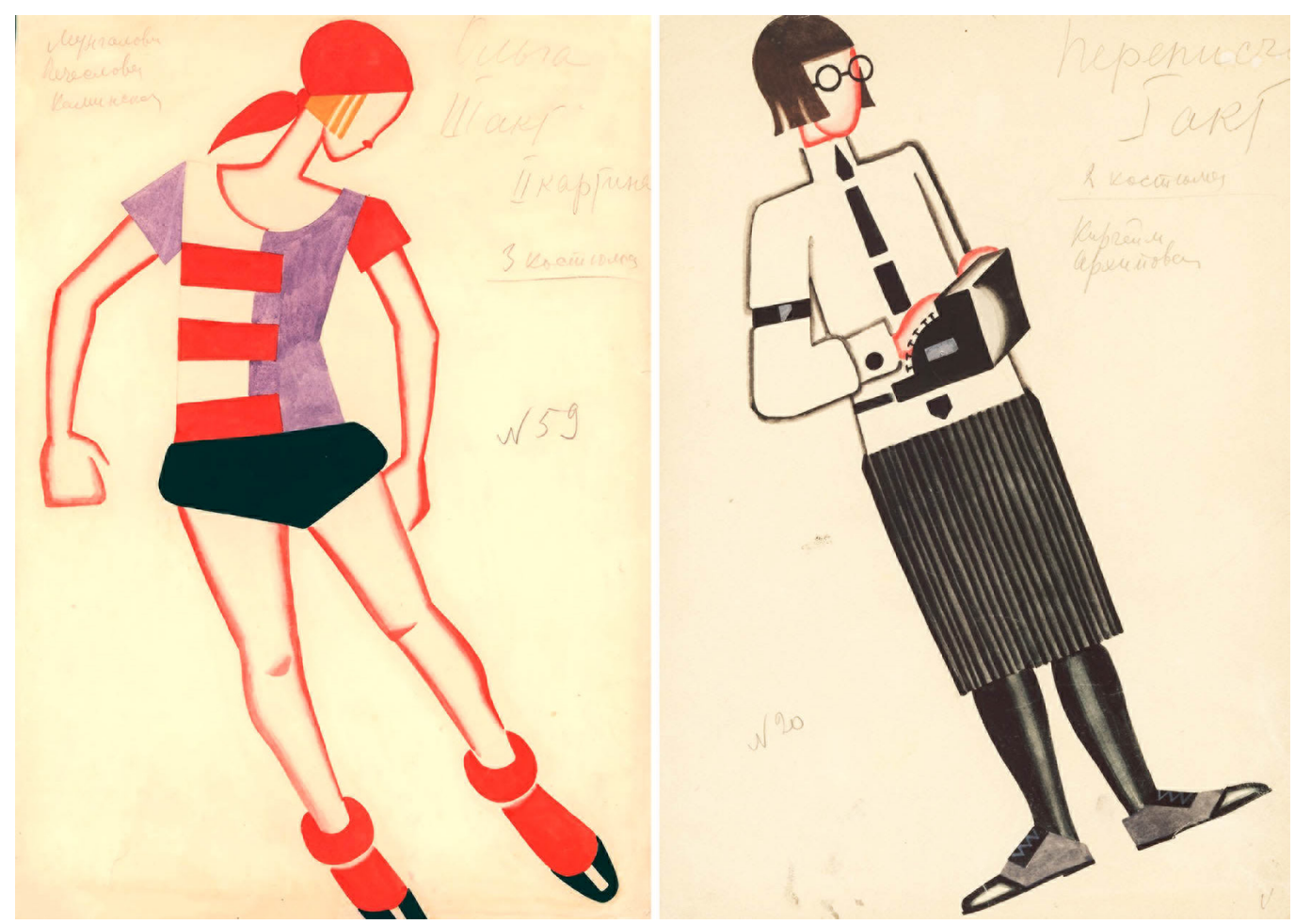

An important connection between the dimension of dance and that of the graphics of the body moving in space is represented by the collaboration between the choreographer Bronislava Nijinska and numerous artists including Igor Stravinsky, Michail Larionov, Natalia Gončarova, Georges Braque, Pablo Picasso. Among these, a vast graphic production on stage costumes is attributed to Alexandra Exter, who in 1925 produced a large number of sketches for a show without sets created by Nijinska herself, who was defining her theories on choreography and abstract compositions in those same years. On the need for a movement that can be visualized for its graphic transcription, the choreographer stated: "one should not start a ballet from the form and then force the movement into this predetermined (improper, lifeless) form [...] The choreographer must make the movement visible to the artist/interpreter and must teach him to reveal it and in turn make it visible to the spectator" [Carandini 1996, p. 33]. 
The attention is then placed on the dancer's microstructures in the development of the action that enhances his/her dynamic qualities in space, marking above all the expressiveness of the trunk and upper limbs. In this vision of the body transformed into the drawing of movement, Alexandra Exter's work is placed as an integral part of the choreographic construction work, the artist often took part in Nijinska's lessons, regularly welcoming dancer students to her atelier. Contaminations of Exter's graphic compositions can be found in the diaries in which she wrote down her choreographies; these are diagrams characterized by circumferences, broken lines, arcs, parabolas and ovals, as well as in costume sketches made by Exter. Her 'theatrical constructivism' is transposed from the machine-scenography to the machine-body when her attention to the gear of the arts is strongly manifested in the show Thamyris Kithardos, which marked the beginning of her collaboration with Tairov in 1915 at the Teatro da Camera.
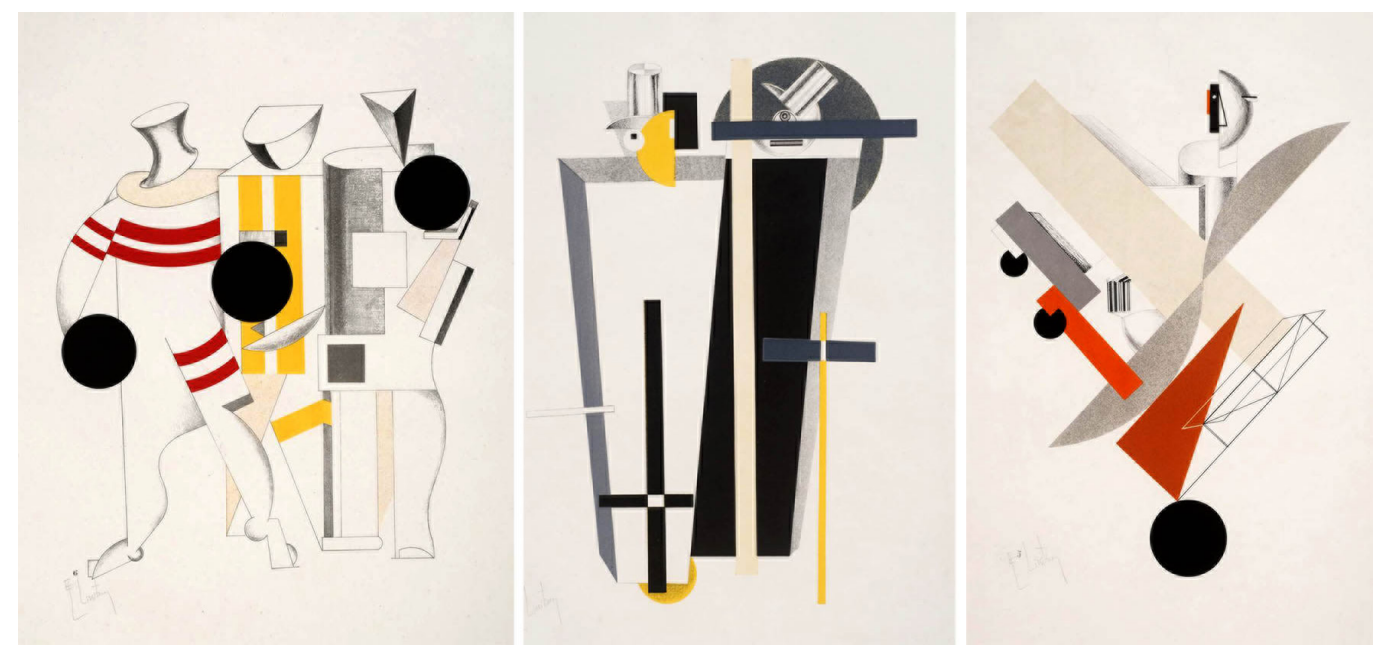

\section{Conclusions}

The graphic reflection on the body-costume constitutes a meeting point between the sign medium of the theatrical space in which the dancer moves and the space of the drawing in which the form and colour are arranged. The costumes follow the dancers' musculature and the graphic structure reproduces a rhythmic-choreographic composition with emphasis on the dynamic qualities of the bodies.

Emanations of signs and colours, the representations of the bodies transfigured in the execution of the gesture, from the hand of dancer-costumists, French advertisers or adepts of the artistic avant-garde, constitute multiple points of contact between the poetics of the body in music and its transfiguration in the stage costume. The representation of this 'double' celebrates a linguistic mimicry that introduces a sort of métachorie [I], an overcoming of dance through the word of drawing.

\section{Notes}

[I] On the concept of Métachorie see the text: Bentivoglio M., Zoccoli F. (2008). Le futuriste italiane nelle artivisive. Roma: De Luca Editori d'Arte, pp. I I-22. 
Fig. 7. Exter A., sketches for stage costumes. Costume for The Phantom Lady, 1924 (on the left); costumes for Aelita in Inhabitant of Mars, 1924 (on the centre and right)
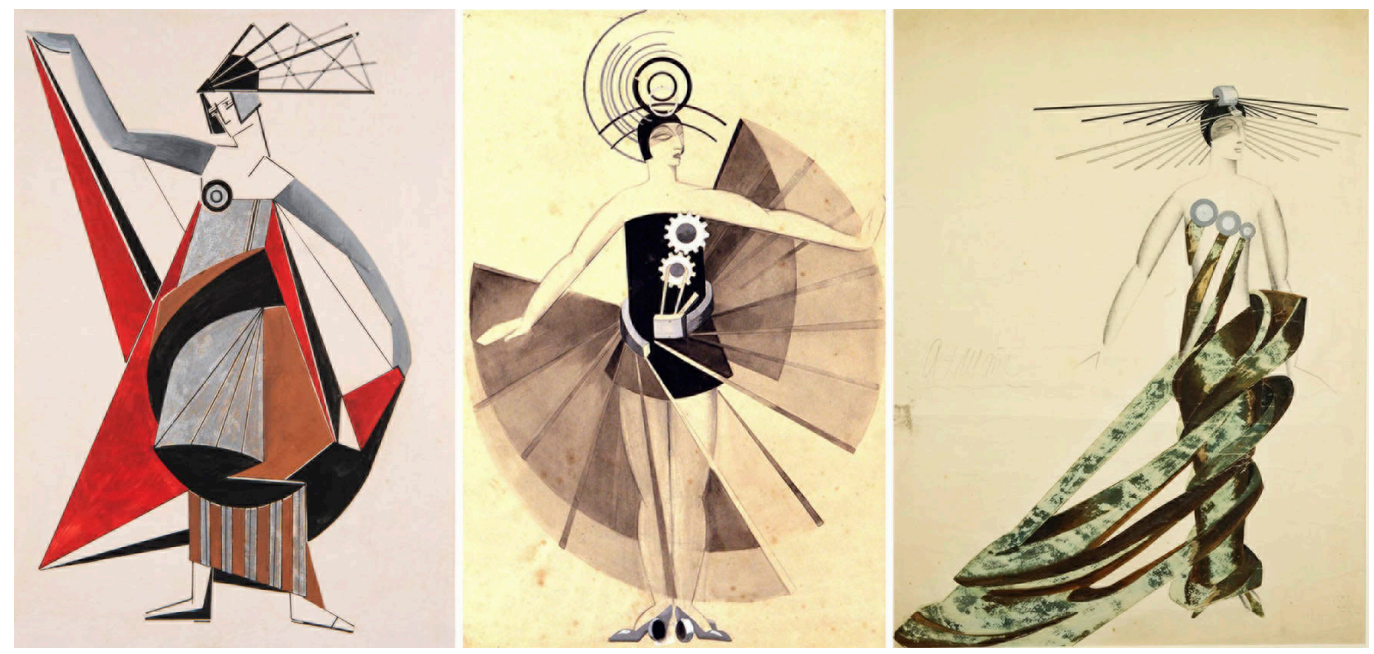

\section{References}

Bentivoglio Mirella, Zoccoli Franca (2008). Le futuriste italiane nelle artivisive. Roma: De Luca Editori d'Arte, pp. 254.

Bredekamp Horst (20।5). Immagini che ci guardano. Varese: Raffaello Cortina Editore.

Carandini Silvia (a cura di) (1996). L'astrazione danzata. Le arti del primo Novecento e lo spettacolo di danza. In Ricerche di Storia dell'Arte, n. 58. Roma: La Nuova Italia Scientifica.

Crane Walter (1914). Line and form. Londra: London G. Bell.

Pierantoni Ruggero (1999). Forma fluens. Il movimento e la sua rappresentazione nella scienza, nell'arte e nella tecnica. Torino: Bollati Boringhieri.

Veroli Patrizia (a cura di). ( 99 I). Un mito della danza fra teatro e avanguardie artistiche. Bologna: Edizioni Bora.

Vinca-Masini Lara (a cura di). (2000). II Liberty. Art Nouveau. Firenze: Giunti.

Author

Starlight Vattano, Libera Università di Bolzano, starlight.vattano@unibz.it

To cite this chapter. Vattano Starlight (2020). Manifesti e bozzetti di scena: la danza come metafora del corpo/Posters and stage sketches: dance as a metaphor for the body. In Arena A., Arena M., Brandolino R.G., Colistra D., Ginex G., Mediati D., Nucifora S., Raffa P. (a cura di). Connettere. Un disegno per annodare e tessere. Atti del $42^{\circ}$ Convegno Internazionale dei Docenti delle Discipline della Rappresentazione/Connecting Drawing for weaving relationships. Proceedings of the 42 th International Conference of Representation Disciplines Teachers. Milano: FrancoAngeli. PP. $1450-1465$. 